in Lisbon last week, where European Union (EU) research ministers met with heads of European science organizations and a handful of Nobel laureates, that he is not sure the interpretation was legal.

The ministers will now ask the commission to reverse its decision not to distribute money to the service facilities, said Gago. If the commission disagrees, he said, then the ministers will take a decision at their next formal meeting in June to unambiguously change the rules.

"Clearly the decision was not what the council of ministers intended," Gago told Nature. "All the ministers think the situation is quite unfair and should be resolved immediately. The ministers did not decide [to stop funding for EBI and EMMA] ... it was a decision by the commission which was taken in a bureaucratic way during the summer holidays."

Gago says the ministers believe infrastructure support to be "essential" for research and development in Europe.

Glauco Tocchini-Valentini, secretary general of the European Molecular Biology Conference, welcomes Gago's statement. "Facilities like EBI and EMMA are close to catastrophe, so intervention at the political level is urgently needed."

But the commission remains reluctant to "create a precedent for direct financing of infrastructures", says a spokeswoman. The FP5 budget is limited, and demand, particularly in the life sciences, is growing, she says. The commission is setting up a working group to look into other options for saving EMMA and EBI.

The Lisbon meeting was the first time that EU research ministers had met with such a wide range of representatives from the scientific community. The EU no longer has a formal European scientific advisory structure. The advisory European Science and Technology Assembly, which was associated with FP4, was dissolved two years ago by former research commissioner Edith Cresson (see Nature $394,817 ; 1998)$ and has not been replaced.

Nobel laureates at the meeting heavily criticized EU peer review systems and called for transparency and efficiency. Gago told Nature he thought a formal mechanism was needed for closer cooperation between the scientific community, the council and the commission. "The European research organizations and the national research councils must be part of the normal consultation process of the council and the commission," says Gago. Natasha Loder

\title{
New form of hydrogen power provokes scepticism
}

Washington

A company claiming to have made a revolutionary breakthrough in chemistry and energy production by creating a novel form of hydrogen has threatened several prominent physicists with possible legal action unless they stop disparaging the science behind the claim.

A law firm representing the energy company BlackLight Power, Inc. of Cranbury, New Jersey, sent letters earlier this month to Nobel laureate Philip Anderson of Princeton University, Michio Kaku of the City University of New York, Paul Grant of the non-profit energy agency EPRI and Robert Park of the American Physical Society, requesting that they stop making defamatory comments in the press about the company and its president, Randell Mills.

BlackLight has already attracted more than $\$ 20$ million in private investment to back its proprietary chemical process. According to Mills, this process has generated energy far in excess of that put into the system. Underlying the process is Mills's theory that hydrogen atoms can be made to exist below their ground state in a form he calls "hydrinos".

The four scientists cited by BlackLight have been quoted in the The Village Voice, Dow Jones Newswire and other publications as dismissing the claim because it violates established principles of physics. Kaku, commenting on the company's investors, which include several large utility companies, was quoted by the Dow Jones Newswire as saying "There's a sucker born every minute".

The negative publicity comes at a bad time for BlackLight, as the company is considering a public stock offering this year. Mills accuses his critics of "trying to destroy our business", and bristles at the charge that he has produced no data to back his claims.

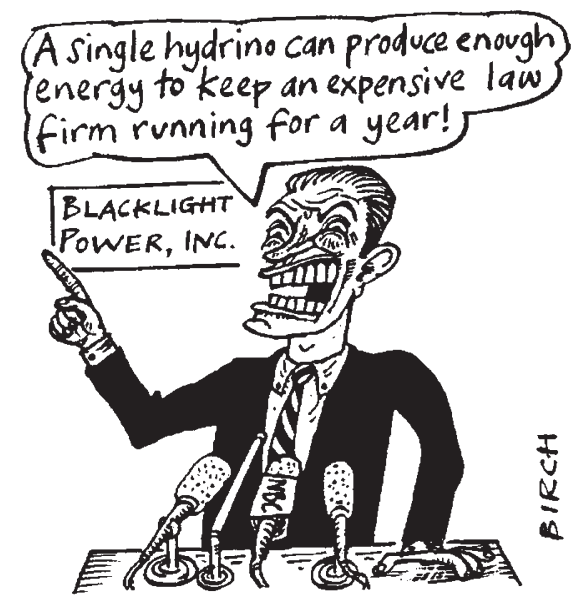

He points to a conference presentation he gave last year at a regional meeting of the American Chemical Society, and says he intends to present at the society's national meeting this month.

He also says he is preparing papers for submission to major scientific journals, and that others have replicated his results and are also submitting to journals.

So far, though, Blacklight's results have been published only on the company's website (www.blacklightpower.com) or in journals that many mainstream scientists say lack rigor and are dominated by other researchers investigating unconventional some say impractical — forms of energy.

Nor has the company's recent award of a US patent for "Lower-energy hydrogen methods and structures" impressed the critics. Grant, an expert in high-temperature superconductors, was quoted by Dow Jones as saying, "A patent means nothing. It carries no weight as scientific validation." The patent examiners based their decision on presentations by BlackLight, according to Mills.

Park says, "the issue is not whether their stuff is out there for review. The issue is whether anybody believes it, and whether people who don't believe it have a right to say they don't believe it." He continues to discount BlackLight's claims as "pure boloney", and will say so in his book, Voodoo Science, due to be published by Oxford University Press this spring. "There'll be no changes," he says.

Despite the implied threat in his letter, BlackLight's attorney Michael O’Hayre says that "we're not interested in stifling any free and open debate. Right now we're just investigating what to do."

Park says he has turned the letter over to the solicitor at the American Physical Society, and is confident that, should BlackLight decide to sue, the courts would side with the physicists. The scientific community would also be likely to rally round the defendants, he says, just as they did a decade ago when lawyers for proponents of cold fusion sent out threatening letters.

Although legal threats in scientific disputes are surprisingly rare, Park says scientists can be "pretty easy to intimidate". With legal fees to defend against a libel charge sometimes running to tens of thousands of dollars, he admits some scientists could decide that it's not worth the risk speaking to the press about controversial research. And that, he says, would "leave the public vulnerable”. 